\title{
DEVELOPING POP-UP BOOK OF CHEMICAL HOUSEHOLD TOPIC FOR JUNIOR HIGH SCHOOL LEVEL
}

\author{
Ghery Priscylio ${ }^{*}$, Rini Fath Marsya ${ }^{2}$, Latisma $^{3}$ and Andromeda ${ }^{3}$ \\ ${ }^{1}$ Natural Science Education, School of Postgraduates, Universitas Pendidikan Indonesia, Jalan \\ Setiabudhi No. 229 Bandung, West Java, 40154 Indonesia \\ ${ }^{2}$ Chemistry Education, School of Postgraduates, Universitas Pendidikan Indonesia, Jalan \\ Setiabudhi No. 229 Bandung, West Java, 40154 Indonesia \\ ${ }^{3}$ Chemistry Education, Fakulltas Matematika dan Ilmu Pengetahuan Alam, Universitas Negeri \\ Padang, Jalan Prof. Dr. Hamka Air Tawar Padang, West Sumatera, 25171, Indonesia \\ *E-mail: ghery.priscylio@upi.edu
}

Received: 10 April 2019; accepted: 22 February 2020; Published: 30 June 2020

\begin{abstract}
This study aimed to develop pop up book on Chemical in Household topic. Method of the study used Research and Development by 4-D stages model; define,design,develop and disseminate. Validation sheet and practically questionnaire were the instrument to collect the data. The pop up book was validated by four experts, 2 lecturers from the Department of Chemistry, Faculty of Mathematics and Natural Sciences, Universitas Negeri Padang, 1 lecturer of FBS Fine Arts, Universitas Negeri Padang and 1 junior high school science teacher. The practicality of the instructional materials was carried out on 1 science teacher and 27 eighth grade students at SMP Negeri 21 Padang. The data obtained were analyzed by using Cohen Kappa Formula. The validity test of the Pop Up book obtained an average value of kappa 0.87 moment with a very high category and a practicality test for the book based on the results of data analysis from teachers' and student questionnaires. The response of teachers' questionnaires obtained a 0.89 kappa moment value with a very high practicality category. The response of students' questionnaires got an average moment value of kappa 0.83 with a very high practicality category. The result also showed that the Pop Up book can increase students' interest to learn and understand science lessons in junior high school level.
\end{abstract}

Keywords: pop up book, chemical in household topic, 4-D models, integrated science

DOI: https://doi.org/10.15575/jtk.v5i1.4086 
G. Priscylio, R. F. Marsya, Latisma \& Andromeda

\section{INTRODUCTION}

The success of the teaching and learning process is the main thing expected in the implementation of education in schools (Hardjo et al., 2017). Teaching and learning process is a process for obtaining information to achieve certain goals (Masna, 2015). There are three main components involved in the teaching and learning process: (1) the instructor (teacher), (2) the learner (student), and (3) the teaching material (subject matter). In the process, there is a transformation of knowledge (teaching materials) from the instructor (teacher) to students. Then, students gain learning experiences from the results of the transformation (Anwar, 2017). Good teachers are not only able to master the subject matter to be taught but also to have good skills in creating teaching materials that can attract student interest so that students are actively involved in the teaching and learning process (Rachmawati, et al., 2015). The teaching material is an important part of the learning process occupying a position that determines the success of teaching and learning related to the achievement of learning objectives (Hamalik, 2008).

One subject in Junior High School (SMP) which is still considered difficult for most students is the Nature (IPA) (Priscylio et al., 2018). Natural Science or science studies natural phenomena which include living creatures and non-living creatures or science about life and science about the physical world (Rahayu et al., 2012). Natural Science is a concept of the learning of nature and it has a very broad relationship related to human life (Mustofa \& Syafi'ah, 2018). Natural Science consists of products and processes. Natural Science as a product is well-organized knowledge about the natural physical world, while Natural Science as a process includes activities to explore, observe and conduct experiments (Shofiyah \&
Developing Pop-Up Book of Chemical Household Topic for Junior High School Level

Wulandari, 2017). A current fact in science subjects in Junior High School shows that students are less actively involved in the learning process (Priscylio et al., 2018). This condition is also influenced by the availability of teaching materials that can attract students' interest in learning Natural Science concepts because students tend to prefer something interesting and unique. Students' interest in something will bring up their inner motivation to find out more about it (Choi \& Jung, 2011). One effort to increase student motivation and learning interest in Natural Science is the use of teaching materials in the form of pop-up books.

Pop-up teaching material is a set of systematically compiled material that is printed with a combination of pop-ups so that when opened, every page looks more dimensional (Masna, 2015). Pop-up Book is a book-shaped media that has threedimensional and motion elements. In a Popup Book, the subject is delivered in the form of interesting pictures because there are parts that move, change or give the impression of arising when opened (Pramesti, 2015). Popups tend to be more mechanical in the papermaking that can make images look more different both in terms of perspective and dimensions and shape changes so they can move as naturally as possible. With pop-ups, the subject presented provides a more interesting visualization and there are interactivities from the sense of touch starting from the appearance of images that appear to have more dimensions and images that can move when each page is opened (Arifin et al., 2018). In addition to using pop-up books in science learning, teachers can also teach the process of making teaching materials in the form of pop-up books in learning activities so that students are also directly involved in the creating process. Student involvement in creating pop-up books will encourage them to 
Developing Pop-Up Book of Chemical Household Topic for Junior High School Level

innovate and practice critical thinking skills, creative thinking, problem-solving skills and opportunities to express their ideas (Smith, 2012). Thus, the learning process is not only teacher-centered but also student-centered. In student-centered learning, the use of popup books helps teachers to create an active and fun learning process because in addition to being pictorial and interesting to students, learning with pop-up books can also stimulate student curiosity, activities and thinking skills. Thus, students can understand the subjects available in pop-up books well (Rosidah et al., 2018).

In this study, the researchers chose to develop a pop-up book on the subject of household chemistry. Household chemistry is one of the subjects of chemistry in the eight-grade in the odd semester. The subjects discussed on the subject of household chemistry include cleaning, bleaching, deodorizing and insect repellent. Indicators that must be achieved by students are mentioning chemicals that can be utilized in daily life and explaining the side effects of chemicals found in household products. The use of chemicals in households can be grouped into 4 parts including cleaning, bleaching, deodorizing, and insect repellent. Cleaning agents are needed to deal with stubborn dirt. Bleaching chemicals are used to whiten and can also function as disinfectants. Deodorizing chemicals are used in perfumes, air fresheners, cleaning agents, fabric softeners, and others. Insect Repellent used to prevent and kill insects. The chemical contents that are often used in households have positive or negative effects on the users and the surrounding environment. Positive effects arise if the chemicals are used according to the rules. Negative effects arise if the chemicals are overused or not according to the rules. Prevention efforts are needed to reduce the dangers arising from the side effects of using household chemicals.

The topic of household chemistry is very interesting and close to student life. However, at present, teachers tend to only use teaching materials in the form of books that cause students to get bored and not interested in learning the concepts of science. For these reasons, teaching materials that can attract student attention, increase student interest in reading, and make them feel excited about learning are needed. At the developmental stage, students at the eight-grade are individuals who are in the adolescent stage marked by their considerable curiosity about something new. They also like objects that have visual appeal. Thus, teaching materials in the form of pop-up books have the potential to be developed on the topic of household chemistry. The use of teaching materials in the form of pop-up books can attract students' attention and can provoke students' curiosity to know something in a more fun way. Teaching materials in the form of pop-up books are alternatives in developing teaching materials with the potential to attract student attention and foster student motivation in learning. For these reasons, it is necessary to develop teaching materials in the form of popup books on the subject of household chemistry for science learning in Junior High School.

\section{RESEARCH METHOD}

\subsection{Research Type}

This research belongs to the category of Research and Development ( $\&$ \& D) method. $R$ $\& D$ is a process or a way to develop a new product or improve existing products in which all activities can be accounted for (Sugiyono, 2014). According to Borg \& Gall, Research and Development is a process used to develop and validate educational products. From this description, Research and Development can be interpreted briefly as a type of research that produces products to be validated and tested 
G. Priscylio, R. F. Marsya, Latisma \& Andromeda

by the relevant experts. Following the definition of Research and Development, this research was conducted to produce a new product in learning, namely the pop-up book teaching material for the subject of household chemistry for eighth-grade students.

\subsection{Teaching Material Development Model}

The development model used was a 4-D model developed by Thiagarajan, Semmel, and Semmel in 1974. This model consists of 4 stages of development, namely: define, design, develop, and disseminate (Trianto, 2012). This development was limited to the stage of "develop" because of limited time, energy, and cost. The flow of teaching material development in the form of pop-up books is illustrated in Figure 1.

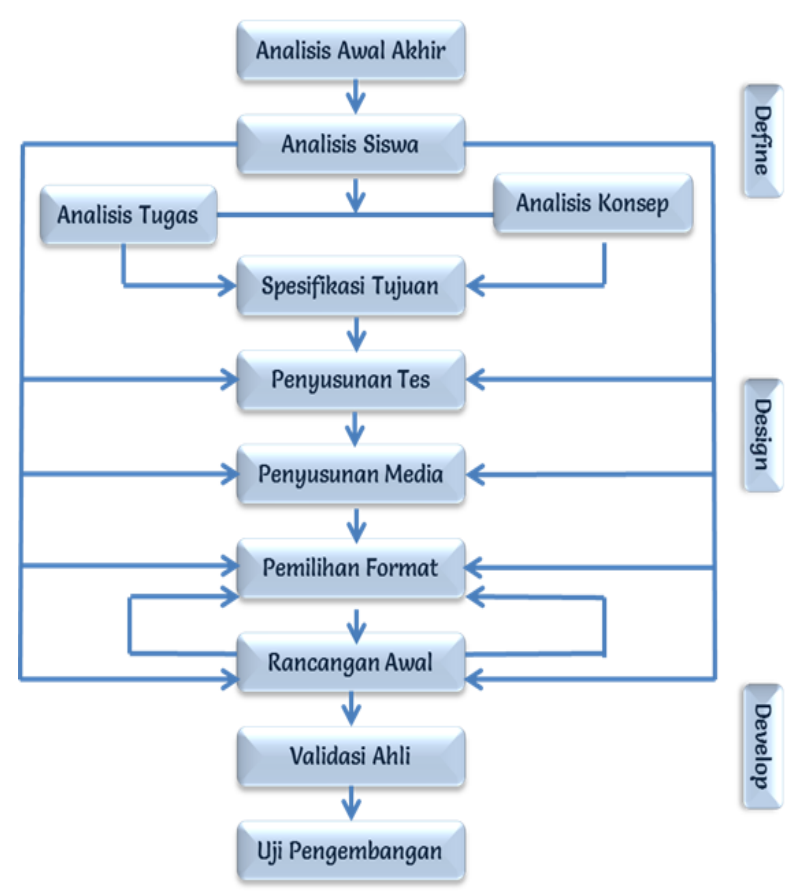

Figure 1. Flowchart of Pop-up Book Teaching Material Development

\subsection{Research Procedures}

The research procedures carried out were under the stages of the 4-D development model consisting of the stages of define, design, develop and disseminate. A description
Developing Pop-Up Book of Chemical Household Topic for Junior High School Level

of the activities carried out at each stage was as follows:

\subsubsection{Define (Stage of Define)}

In this stage, the learning conditions were determined and defined. At this stage, there were several analyses performed, namely:

\subsubsection{Front-end Analysis}

Front-end analysis aimed to bring up and determine the basic problems faced in chemistry learning on the subject of household chemistry so that the development of the teaching material is needed. This analysis will get a picture of facts, expectations and alternative solutions to basic problems that facilitate the determination or selection of the teaching material developed. The steps taken at this stage were as follows:

1) Interviewing the science teacher concerned.

2) Interviewing ninth-grade students who have studied household chemistry subjects.

\subsubsection{Learner Analysis}

Student analysis is a study of student characteristics following the design and development of learning tools. The steps taken at this stage were as follows:

1) Observing the characteristics of student learning in the ongoing learning process through direct observation carried out by the researchers.

2) Discussing with the science teacher concerned.

\subsubsection{Task Analysis}

Task analysis aimed to identify and analyze the abilities students must master through determining the contents in learning units following the curriculum. Analysis of the tasks carried out in this development included the following.

Jurnal Tadris Kimiya 5, 1 (Juni 2020): 14-25 
Developing Pop-Up Book of Chemical Household Topic for Junior High School Level

1) Analyzing Basic Competencies (KD) of household chemistry subject.

2) Formulating learning indicators.

\subsubsection{Concept Analysis}

Concept analysis is an important step in fulfilling principles in developing concepts on the subject used as a means of achieving Basic Competencies and Competency Standards (SK). Concept analysis is needed to identify the main concepts that will be conveyed, to elaborate, and to systematically arrange relevant concepts that will be developed.

\subsubsection{Analysis of Learning Objectives}

This stage is carried out to formulate the results of task analysis and concept analysis to be indicators of achievement of learning outcomes which subsequently become the learning objectives. The results of the formulation of learning objectives are the basis in the preparation of the design of teaching material.

\subsubsection{Design (Stage of Designing)}

At this stage, the design of pop-up book was carried out on the subject of household chemistry for eight-grade student chemistry learning. This stage included the following matters.

\subsubsection{Teaching Material Selection}

The selection of the teaching material aims to determine the teaching material that is relevant to learning materials. The researchers chose the pop-up book teaching material following the front-end analysis, student characteristics, task analysis, concept analysis and analysis of learning objectives on the subject of household chemistry.

\subsubsection{Format Selection}

The format selection in the development of the teaching material was intended to design learning contents, selection of strategies,

approaches, learning methods, and learning resources. The format chosen was the one that meets the criteria of attracting, facilitating and assisting in household chemistry learning.

The format of the teaching material was adjusted to the format of the Guidelines for the Development of Teaching Materials by the Ministry of National Education in 2008 (Ministry of National Education, 2008). The format of the pop-up book writing in this study was as follows.

1) Front-page (cover)

2) Title/Identity

3) Basic Competencies that will be achieved by students

4) Learning instructions

5) Contents of learning materials

6) Summary

7) Evaluation

8) Bibliography

\subsubsection{Initial Design}

The results of this stage were the initial design of learning tools.

1) Designing the front page (cover)

2) Designing Basic Competencies that will be achieved by students

3) Designing indicators and learning objectives

4) Designing instructions for using pop-up books

5) Designing household chemical essential subjects

6) Determining ideas and pop-up combination forms that will be displayed

7) Creating image design and layout of the pop-up book using Corel Draw and Microsoft Publisher 2010.

8) Preparing basic materials (art paper 260 gram) and equipment (scissors, razor blades, glue, double tape, etc.).

9) Printing layout of the teaching material and parts of pop-ups 
G. Priscylio, R. F. Marsya, Latisma \& Andromeda

10) Making pop-up combination pieces using scissors and razor blades.

11) Arranging pop-ups in the layout of the book in such a way as to produce a book with 3-dimensional visualization.

12) Making the hardcover of the pop-up book.

\subsubsection{Develop (Stage of Developing)}

This stage aimed to produce revised pop-up teaching material based on input from validators. Although many designs have been produced at the design stage, the results were seen as initial versions that must be refined before they become the appropriate final version. This stage consisted of three steps, namely validity test, revision, and trial.

\subsubsection{Validity Test}

This validity test aimed to reveal the validity of the developed pop-up teaching material. Validation was carried out by four lecturers as validators. Criticism, input, and suggestions from the validators were used to revise the pop-up book. In conducting the validity test, the following steps were taken.

1) The researchers asked the willingness of the lecturers to see the feasibility of popup book teaching material and the validity of the concepts that have been made and the validity of the language used.

2) The researchers asked the lecturers to provide an assessment of the pop-up book teaching material made based on the items in the validation sheet and to provide suggestions for the deficiencies that exist in the pop-up book teaching material.

3) After the assessment was carried out, the researchers revised the pop-up book teaching material according to the suggestions given by the validators.
Developing Pop-Up Book of Chemical Household Topic for Junior High School Level

\subsubsection{Revision}

This revision stage aimed to improve parts of the pop-up book teaching material that were considered inappropriate by the validators before the product was tested. The teaching material in the form of the improved pop-up book was then given back to the validators for further discussion before trial. The revision was stopped if the validators have stated that the pop-up book teaching material made was already valid.

\subsubsection{Trial}

The product trial was conducted on a limited number of students at SMPN 21 Padang. This trial aimed to determine the practicality of the pop-up book teaching material. Practicality tests were carried out to determine the extent of the benefits, ease of use and efficiency of learning time by using the pop-up book teaching material. This practicality test was done by giving practicality test questionnaires to the selected science teachers and junior high school students. The practicality test was carried out with the following steps.

1) Practicality Test carried out by the Teachers

a. The researchers gave guidance on how to fill in the questionnaires to the teachers.

b. The researchers provided the pop-up book teaching material to teachers.

c. The researchers gave brief instructions on the use of the pop-up book teaching material.

d. The teachers used the pop-up book teaching material based on the instructions that already exist in the learning process.

e. The researchers asked the teachers to fill out the questionnaires on the practicality of the pop-up book teaching material and to provide suggestions and criticisms. 
Developing Pop-Up Book of Chemical Household Topic for Junior High School Level

2) Practicality Test carried out by the Students

a. The researchers gave directions on how to fill out the questionnaires for students.

b. The researchers distributed the pop-up book teaching material to the students in groups.

c. The researchers provided brief instructions on the use of the pop-up book teaching material.

d. The students were asked to read and understand the contents of the pop-up book teaching material.

e. The students were asked to fill out the questionnaires on the practicality of the pop-up book teaching material.

\subsection{Research Instruments}

Data collection instruments are tools that are chosen and used in collecting data so that these activities become systematic and easy (Riduwan, 2009). The instruments used in this study were as follows.

\subsubsection{Validation Sheets}

The validation sheets were used to assess the content validity and construct validity of the pop-up book teaching material. Content validity relates to whether the instruments have included all dimensions and all indicators completely from the concepts to be measured. Meanwhile, construct validity is the validity that looks at whether or not the instruments are composed of a systematic theoretical framework. The validation sheets were filled in by experts from chemistry lecturers and chemistry teachers. The data obtained were used to reveal the level of validity of the designed pop-up book teaching material.

\subsubsection{Practicality Questionnaires}

The questionnaires given were student and teacher responses' questionnaires on the popup book teaching material that was used during the product trial. The data obtained

were used to determine the practicality of the use of the pop-up book teaching material during the learning process.

\subsection{Data Analysis Techniques}

\subsubsection{Validity Analysis Technique}

The validators' evaluation of each statement was analyzed using the Cohen Kappa Formula where at the end of the process a kappa moment was obtained.

$$
\text { moment kappa }(k)=\frac{P-P e}{1-P e}
$$

\section{Notes:}

$\mathrm{k}=$ kappa moment which shows the product validity

$\mathrm{P}=$ realized proportion, calculated by dividing the total score given by the validators with the maximum total score.

$\mathrm{Pe}=$ unrealized proportion, calculated by subtracting the total score given by the validators from the total maximum score, then divide it with the total maximum score (Boslaugh, 2012).

Table 1. Decision Categories based on Kappa Moment (k)

\begin{tabular}{|c|c|}
\hline Interval & Categories \\
\hline $0,81-1,00$ & Very high \\
\hline $0,61-0,80$ & High \\
\hline $0,41-0,60$ & medium \\
\hline $0,21-0,40$ & Low \\
\hline $0,01-0,20$ & Very low \\
\hline 0,00 & not valid \\
\hline
\end{tabular}

\subsubsection{Practicality Analysis Technique}

Practicality analysis techniques of the pop-up book teaching material were based on questionnaire data that have been filled out by the teachers (teacher response questionnaires) and students (student response questionnaires). This study used a closed questionnaire Likert scale model arranged with five scales, namely: Strongly Agree (SS), Agree (S), Disagree (TS) and Strongly Disagree 
G. Priscylio, R. F. Marsya, Latisma \& Andromeda

(STS). For analysis, the data obtained were processed using the Cohen Kappa formula.

\section{RESULT AND DISCUSSION}

\subsection{Teaching Material Validity Test}

Here, we present the data on the results of the Mean score of Moment Kappa validity test of the teaching material.

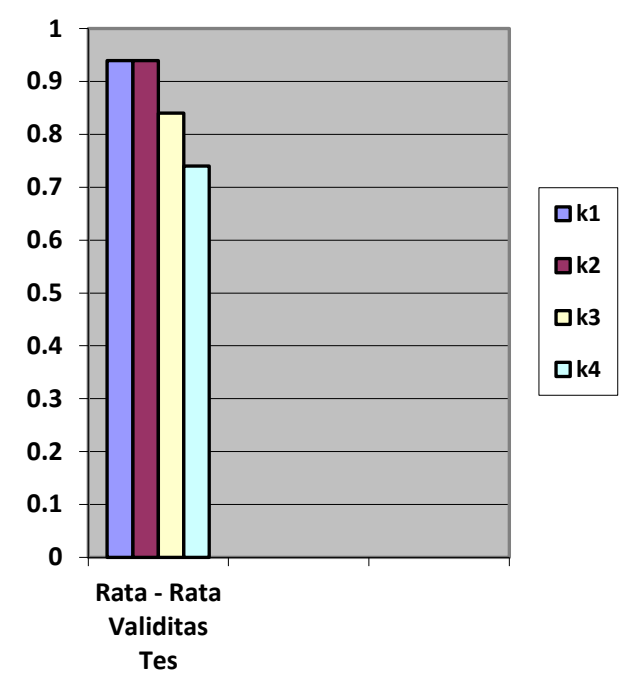

Figure 2. Mean Score of Moment Kappa
Validity Test

In Figure 2 it can be seen that the four validators gave different scores. The Mean score of Moment Kappa ( $k$ ) validator $1(k 1)$ was 0.94 with a very high category, the Mean score of Moment Kappa validator 2 (k2) was 0.94 with a very high category, the Mean score of Moment Kappa validator 3 (k3) was 0.84 with a very high category, and the Mean score of Moment Kappa validator $4(\mathrm{k} 4)$ was 0.74 with a high category. Overall, it can be seen that of the four validators, 3 validators gave very high or very valid ratings and 1 validator gave a valid rating. Based on the Mean score of Moment Kappa above, we can conclude that the teaching material developed by the researchers, namely the pop-up book teaching material, has met the criteria in accordance
Developing Pop-Up Book of Chemical Household Topic for Junior High School Level

with the assessment tools (validation sheets) in terms of contents, construct, language, and graphics. In addition, the developed teaching material has been arranged based on indicators of achievement of developed competencies. A product is said to be valid if the product can show a condition that is in accordance with the contents and constructs (Arikunto, 2008).

\subsection{Teaching Material Practicality Test}

Table 2. Mean Score of Moment Kappa Validity Test

\begin{tabular}{|l|c|}
\hline \multicolumn{1}{|c|}{ Practicality Test } & $\begin{array}{c}\text { Mean Score of } \\
\text { Moment Kappa (k) }\end{array}$ \\
\hline $\begin{array}{l}\text { Teacher-response } \\
\text { questionnaires }\end{array}$ & 0.89 \\
\hline $\begin{array}{l}\text { Student-response } \\
\text { questionnaires }\end{array}$ & 0.83 \\
\hline
\end{tabular}

The obtained of kappa moment score $(k)$ from the teacher-response questionnaires on the practicality of the teaching material developed which was 0.89 with a very high category indicated that the pop-up book teaching material for the subject of household chemistry was following with the Basic Competencies, indicators and learning objectives, and other important information. Then, the pop-ups could attract the students' attention in reading and learning. Besides, the pop-up book was also easy to use and the time needed to make use of it was also efficient.

The obtained of kappa moment score $(\mathrm{k}) 0.83$ which was in a very high category indicated that the pop-up book teaching material for the subject of household chemistry produced was in a very high practicality category to be used in the learning process. The use of colors, designs, and 3-dimensional visualization in the pop-up book made students very interested in learning. Based on these results, it can be concluded that the pop-up book teaching 
material for the subject of household chemistry could attract student attention and made students feel excited to learn.

\subsection{The Display of The Pop-up Book Teaching Material}

The display of the pop-up book teaching material that has been developed can be seen in Figures 3,4,5,6 and 7.

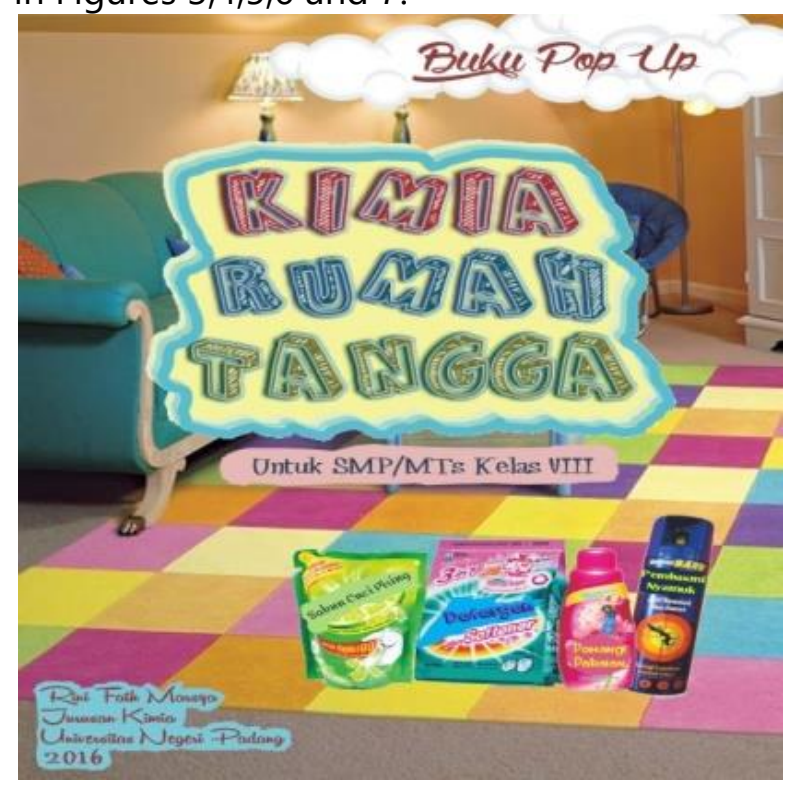

Figure 3. Draft of Pop-up Book Cover

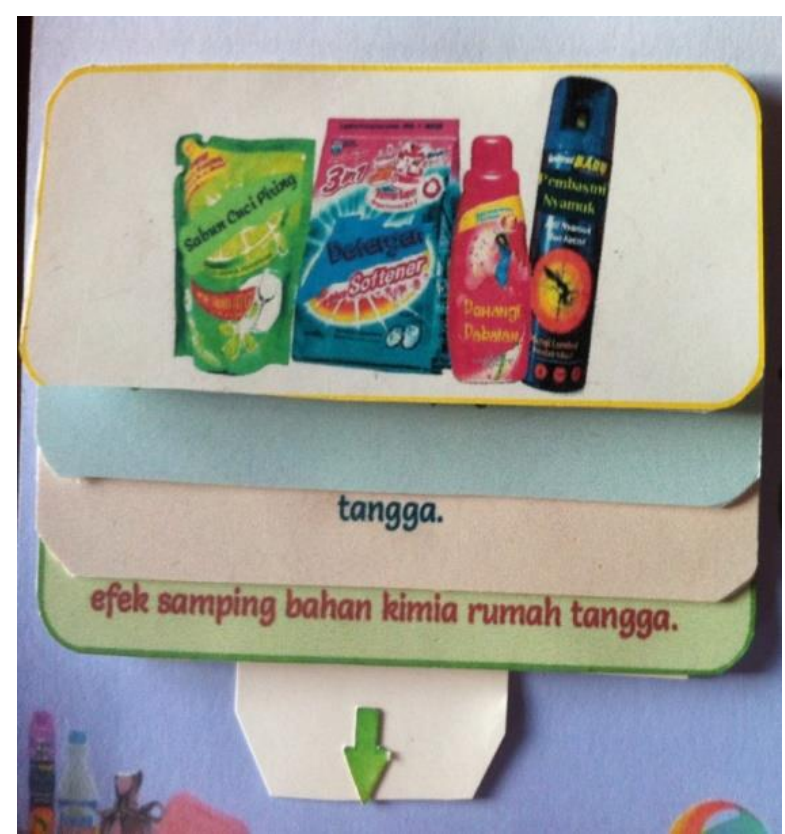

Figure 4. Draft of Pop-up book Basic Competencies

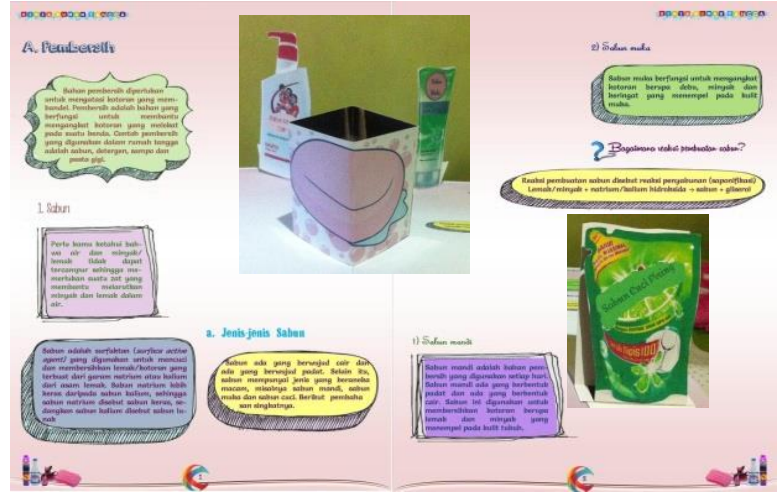

Figure 5. Draft of Pop-up Book Content

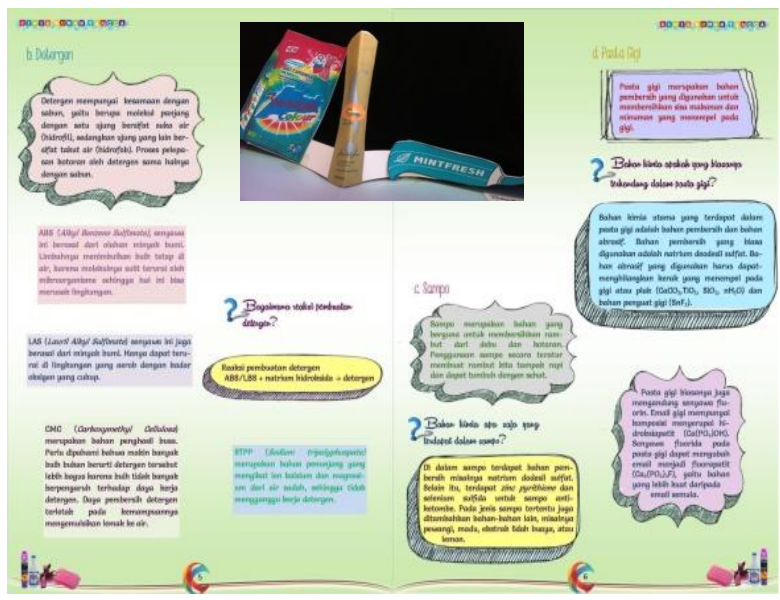

Figure 6. Draft of Pop-Up Book Content on page 5 and page 6

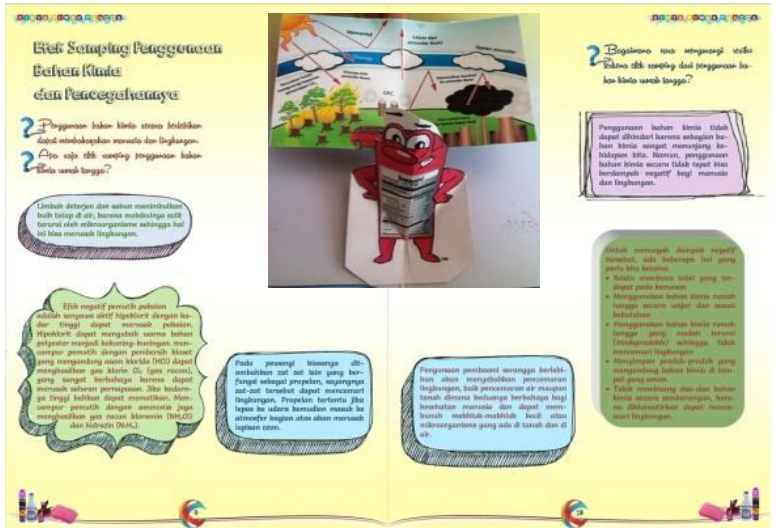

Figure 7. Draft of Pop-up Book Content on page 9 and page 10 
G. Priscylio, R. F. Marsya, Latisma \& Andromeda
Developing Pop-Up Book of Chemical Household Topic for Junior High School Level

\section{CONCLUSION}

Based on the research that has been done, it can be concluded that this $R \& D$ research has produced a pop-up book teaching material for the subject of household chemistry for eighthgrade students which had very high validity and practicality. The finding indicated that the pop-up book teaching material was strongly related with the Basic Competencies, indicators and learning objectives on the subject of Household Chemistry and can be used well by teachers and students in the teaching and learning process of science in Junior High School. 


\section{REFERENCES}

Anwar, S. (2017). Pengolahan Bahan Ajar. Bandung: Universitas Pendidikan Indonesia.

Arifin, M. Y., Kirana, T., \& Widodo, W. (2018). Pembelajaran Inkuiri Terbimbing untuk Meningkatkan Kemampuan Bernalar Siswa Kelas VI Berbantuan Media Buku Pop Up. Jurnal Penelitian Pendidikan IPA, 2(1), 6-10.

Arikunto, S. (2008). Dasar-Dasar Evaluasi Pendidikan. Jakarta: Bumi Aksara.

Boslaugh, S. (2012). Statistics in a Nutshell: $A$ Desktop Quick Reference. United State of America: O'Reilly Media, Inc.

Choi, J. S., \& Jung, E. T. (2011). Developing a Pop-up Making Book Application for iPAD. Journal of Integrated Design Research, 10(1), 69-78.

Hamalik, O. (2008). Perencanaan Pengajaran Berdasarkan Pendekatan Sistem. Jakarta: Bumi Aksara.

Hardjo, F. N., Retnowati, R., \& Rostikawati, T. (2017). Model Pembelajaran Student Teams Achievement Divisions dengan Media Pop Up Card untuk Meningkatkan Hasil Belajar Biologi Kelas XI IPA 1 SMA Siliwangi Bogor. JPPS (Jurnal Penelitian Pendidikan Sains), 6(2), 1334-1339.

Masna, A. A. (2015). Pengembangan Bahan Ajar Pop-Up Mata Pelajaran IPA Untuk Anak Tunarungu Kelas IV SDLB B di Yogyakarta. E-Jurnal Skripsi Program Studi Teknologi Pendidikan, 4(1).
Mustofa, R., \& Syafi'ah, R. (2018). Pengembangan Media Pembelajaran Pop Up Book Materi Pokok Kenampakan Permukaan Bumi pada Mata Pelajaran IPA Kelas III SDN 1 Banaran Kecamatan Kauman Kabupaten Tulungagung. ELSE (Elementary School Education Journal): Jurnal Pendidikan dan Pembelajaran Sekolah Dasar, 2(2), 30-41.

Pramesti, J. (2015). Pengembangan Media Pop-Up Book Tema Peristiwa Untuk Kelas III SD. Jurnal Pendidikan Guru Dan Sekolah Dasar, 4(16), 1-13.

Priscylio, G., Mulyadi, M., \& Rochintaniawati, D. (2018). Needs of Integrated Science Experiment Student Worksheet in Junior High School to Improve Students Science Process Skills. In International Conference on Mathematics and Science Education of Universitas Pendidikan Indonesia, 3, 481-485.

Rachmawati, R., Rahmatan, H., \& Hasanuddin, H. (2015). Penerapan Bahan Ajar Media Komik pada Konsep Fotosintesis untuk Meningkatkan Hasil Belajar Peserta Didik di Smp Islam Darul Ulum Banda Aceh. Jurnal EduBio Tropika, 3(1).

Rahayu, P., Mulyani, S., \& Miswadi, S. S. (2012). Pengembangan Pembelajaran IPA Terpadu dengan Menggunakan Model Pembelajaran Problem Base melalui Lesson Study. Jurnal Pendidikan IPA Indonesia, 1(1), 63-70.

Riduwan. (2009). Statistika Bagi Peneliti Pemula. Jakarta: Rineka Cipta.

Rosidah, T., Anisa, F., Savira, N. F., \& Hidayah, F. F. (2018). Phase Define: Pop-Up Book as A Media Learning Elementary School Student based Indigenous Science 1, 2, 
G. Priscylio, R. F. Marsya, Latisma \& Andromeda

3, 41 Local Wisdom Farmers Village Salt Jono. In Prosiding Seminar Nasional \& Internasional, 1(1).

Shofiyah, N., \& Wulandari, F. E. (2017). Pelatihan Pembuatan Pop Up Book sebagai Media Pembelajaran Sains bagi Guru Taman Kanak-Kanak. Jurnal ABDI: Media Pengabdian Kepada Masyarakat, 3(1), 32-35.

Smith, S. (2012). Go to Your Classroom and Make Meaning: Using the Digital Fabrication Process to Make Original Pop-up Books in an Afterschool Program. Society for Information Technology \& Teacher, 1070-1074.

Sugiyono. (2014). Metode Penelitian Pendidikan. Bandung: Alfa Beta.

Trianto. (2012). Model Pembelajaran Terpadu. Jakarta: Bumi Aksara.
Developing Pop-Up Book of Chemical Household Topic for Junior High School Level 